\title{
SPATIAL VARIABILITY IN THE SPECIATION AND BIOACCUMULATION OF MERCURY IN AN ARID SUBTROPICAL RESERVOIR ECOSYSTEM
}

\author{
Jesse C. Becker, $* \dagger$ Alan W. Groeger, $\dagger$ Weston H. Nowlin, $\dagger$ Matthew M. Chumchal,$\ddagger$ and Dittmar Hahn $\dagger$ \\ $\dagger$ Department of Biology, Texas State University-San Marcos, Aquatic Station, San Marcos, Texas, USA \\ $\ddagger$ Department of Biology, Texas Christian University, Fort Worth, Texas, USA
}

(Submitted 23 March 2011; Returned for Revision 10 May 2011; Accepted 5 June 2011)

\begin{abstract}
Patterns of spatial variation of mercury and methylmercury ( $\mathrm{MeHg}$ ) were examined in sediments and muscle tissue of largemouth bass (Micropterus salmoides) from Amistad International Reservoir, a large and hydrologically complex subtropical water body in the Rio Grande drainage. The distributions of both $\mathrm{Hg}$ and $\mathrm{MeHg}$ were compared with environmental and biological factors known to influence production of $\mathrm{MeHg}$. The highest concentrations of total $\mathrm{Hg}(\mathrm{THg})$ in sediment were found in the Rio Grande arm of the reservoir, whereas $\mathrm{MeHg}$ was highest at sites in the Devils River arm and inundated Pecos River (often more than $3.0 \mathrm{ng} / \mathrm{g}$ ). Conditions in the sediments of the Devils River arm and Pecos River channel were likely more favorable to the production of MeHg, with higher sediment porewater dissolved organic carbon, and porewater sulfate levels in the optimal range for methylation. Although the detection of different groups of sulfate-reducing bacteria by polymerase chain reaction (PCR) was generally correlated with MeHg concentrations, bacterial counts via fluorescent in situ hybridization (FISH) did not correlate with MeHg. A sample of 156 largemouth bass $(<30 \mathrm{~cm})$ showed a spatial pattern similar to that of $\mathrm{MeHg}$ in sediments, where fish from the Devils River arm of the reservoir had higher muscle $\mathrm{Hg}$ concentrations than those collected in the Rio Grande arm. In 88 bass of legal sport fishing size ( $>35 \mathrm{~cm}), 77 \%$ exceeded the $0.3 \mathrm{mg} / \mathrm{kg}$ U.S. Environmental Protection Agency screening value. This study shows that significant variation in sediment $\mathrm{MeHg}$ and biotic $\mathrm{Hg}$ concentration can exist within lakes and reservoirs and that it can correspond to variation in environmental conditions and Hg methylation. Environ. Toxicol. Chem. 2011;30:2300-2311. (C) 2011 SETAC
\end{abstract}

Keywords-Mercury Reservoirs Sulfate-reducing bacteria Largemouth bass $\quad$ Rio Grande

\section{INTRODUCTION}

Mercury is a potent toxin of great concern for aquatic ecosystems because of its tendency to bioaccumulate in biota $[1,2]$. Mercury concentrations in the atmosphere are elevated two- to fivefold over preindustrial levels, mainly as a result of worldwide increases in industrial activities such as the burning of fossil fuels [1-3]. Atmospheric deposition has been identified as a major pathway by which $\mathrm{Hg}$ enters aquatic ecosystems, although some soils are naturally rich in $\mathrm{Hg}$, and contamination of downstream ecosystems by areas of past $\mathrm{Hg}$ mining activity is particularly worrisome $[1,4]$. In aquatic ecosystems, natural biological processes can transform inorganic $\mathrm{Hg}$ (the form most commonly found in the environment) into organic methylmercury ( $\mathrm{MeHg}$; the form that has been shown to bioaccumulate) $[1,2]$. Unfortunately, determining the relationship between $\mathrm{Hg}$ loading to a system and biotic $\mathrm{Hg}$ concentrations has proved difficult, because high levels of inorganic $\mathrm{Hg}$ are not required for the production and bioaccumulation of substantial amounts of $\mathrm{MeHg}$, and ecosystems within close proximity often show variability in $\mathrm{Hg}$ concentrations [3]. The concentration of $\mathrm{MeHg}$ in a system is determined in part by the competing processes of methylation and demethylation, which are largely microbially controlled [5]. The relationship between total $\mathrm{Hg}$ ( $\mathrm{THg}$ ) and $\mathrm{MeHg}$ is also affected by the environmental conditions, which influence the activity of the bacteria, as well as the availability of $\mathrm{Hg}$ for methylation $[5,6]$.

All Supplemental Data may be found in the online version of this article.

* To whom correspondence may be addressed

(jcbecker@txstate.edu).

Published online 18 July 2011 in Wiley Online Library

(wileyonlinelibrary.com).
Methylmercury is produced in aquatic sediments primarily by sulfate-reducing bacteria (SRB), with the families Desulfovibrionaceae and Desulfobacteriaceae having high potential for $\mathrm{Hg}$ methylation [7,8]. However, the exact biogeochemical processes and controls of $\mathrm{Hg}$ methylation remain unclear [3]. Some have suggested that it is an enzymatic accident in which $\mathrm{Hg}^{2+}$ receives the methyl group from methylcobalamin [1] or an active detoxification mechanism against inorganic $\mathrm{Hg}$, because $\mathrm{MeHg}$ is slightly more volatile than $\mathrm{Hg}^{2+}$ [7]. Multiple metabolic pathways likely are involved in producing $\mathrm{MeHg}$ [1], which is influenced by both the form of $\mathrm{Hg}$ and complex relationships with several environmental factors related to the activity of SRB, such as ecosystem productivity, temperature, anoxic and redox boundary conditions, sulfate $\left(\mathrm{SO}_{4}^{2-}\right)$, sulfide, chloride $\left(\mathrm{Cl}^{-}\right)$, dissolved organic carbon (DOC), and sediment organic matter $[1,3,9]$. Once produced, $\mathrm{MeHg}$ is concentrated by phytoplankton and bacteria, and consumers are exposed through their diets [1].

Most studies addressing the spatial patterns of $\mathrm{Hg}$ pollution in freshwater systems have involved regional assessment of a large number of lakes and reservoirs [4,9], but substantial variability in $\mathrm{MeHg}$ production and bioaccumulation within ecosystems has recently been appreciated [10,11]. Because of their size and location in the landscape, reservoirs can exhibit spatial complexity not seen in natural lakes [12], and it is reasonable to believe that they would exhibit spatial variability approaching that seen in riverine systems [13]. Large reservoirs are common in many regions, and many are heavily utilized by humans. The Amistad International Reservoir (AIR; Fig. 1) is a large, structurally complex reservoir that provides an opportunity to investigate the spatial patterns of $\mathrm{MeHg}$ production and bioaccumulation in these types of systems. In AIR, large differences in the physiochemical characteristics of the three 


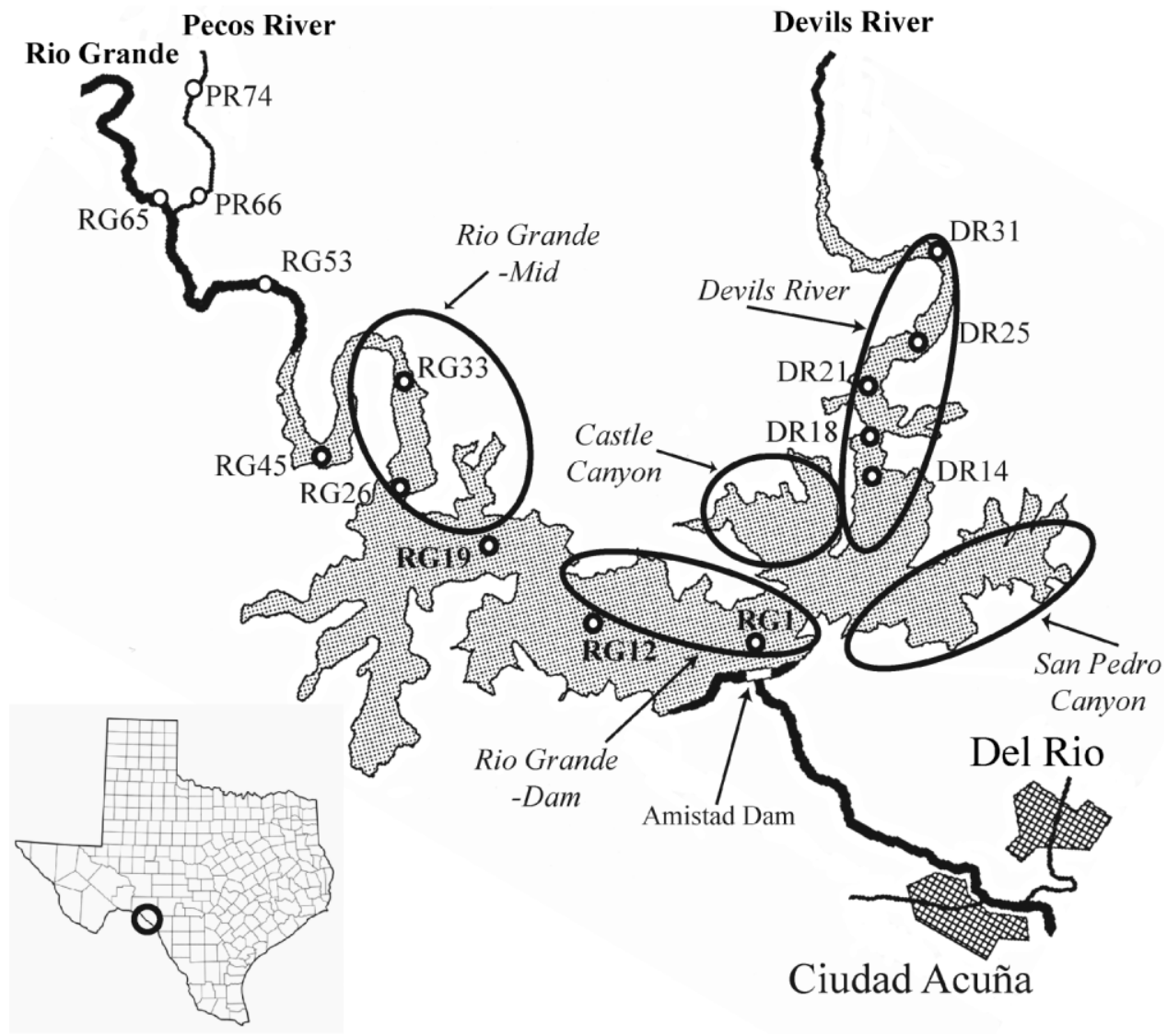

Fig. 1. Map of Amistad International Reservoir showing sediment sampling sites and fish collection areas in the present study. Sediment sampling sites are identified by two letter abbreviations for reservoir arm $(\mathrm{RG}=$ Rio Grande; $\mathrm{DR}=$ Devils River; $\mathrm{PR}=$ Pecos River), followed by a number corresponding to the approximate river channel distance $(\mathrm{km})$ upstream from the dam. Fish collection areas are circled and labeled in italic. Inset map shows location of Amistad International Reservoir in Texas, USA. Map is modified from the Texas Commission on Environmental Quality [16].

main rivers flowing into the reservoir create conditions that could lead to variability in $\mathrm{Hg}$ dynamics throughout the reservoir [14].

The first objective of the present study was to examine the spatial distribution and temporal trends of both $\mathrm{THg}$ and $\mathrm{MeHg}$ concentrations in the sediments of AIR, as well as some of the potential abiotic environmental and microbial influences on $\mathrm{MeHg}$ production and bioaccumulation. We hypothesized that $\mathrm{THg}$ concentrations would be relatively low throughout most of the reservoir, because the primary source of $\mathrm{Hg}$ to the reservoir is likely regional atmospheric deposition, and previous surveys have not suggested highly elevated sediment THg concentrations $[15,16]$. The Rio Grande arm of the reservoir, however, would likely have higher sediment $\mathrm{THg}$ concentrations because it is downstream $(\sim 250 \mathrm{~km})$ from historical $\mathrm{Hg}$ mining areas in the Terlingua/Big Bend region of Texas [17]. We also hypothesized that sediment $\mathrm{MeHg}$ concentrations would be correlated with environmental conditions and bacterial communities, specifically the abundance of SRB.

The second objective was to examine $\mathrm{Hg}$ bioaccumulation in largemouth bass (Micropterus salmoides), a predatory sportfish. We investigated whether spatial variation exists in muscle $\mathrm{Hg}$ concentration of largemouth bass from different areas of the reservoir and whether the $\mathrm{Hg}$ concentration in fish was related to $\mathrm{Hg}$ concentrations in the sediment. We hypothesized that fish would have low muscle $\mathrm{Hg}$ concentrations, but that fish from areas with relatively elevated sediment $\mathrm{MeHg}$ would have higher muscle concentrations of $\mathrm{Hg}$. Spatial variation in the muscle concentration of $\mathrm{Hg}$ has been found in multiple species of fish from different habitat types or environmental conditions [18-20], suggesting that testing fish from only one or two locations in a reservoir may not be adequate to understand the dynamics of $\mathrm{Hg}$ bioaccumulation.

Our third objective was to determine whether adult largemouth bass pose a risk to human consumers. Amistad International Reservoir supports a large recreational fishery on the U.S. side of the reservoir and a commercial fishery on the Mexican side of the reservoir. Consuming fish with elevated $\mathrm{Hg}$ levels is believed to be the primary route by which humans are exposed to $\mathrm{Hg}$ [21]. We hypothesized that $\mathrm{Hg}$ would be present, because even remote areas can be impacted by $\mathrm{Hg}$ pollution and bioaccumulation [3], but we did not expect the levels to be of concern.

\section{MATERIALS AND METHODS}

\section{Study area}

Amistad International Reservoir is located on the border between Texas, USA, and Coahuila, Mexico $\left(29^{\circ} 27^{\prime} \mathrm{N}\right.$; $101^{\circ} 03^{\prime} \mathrm{W}$; Fig. 1). The reservoir has a surface area of approximately $263 \mathrm{~km}^{2}$ and a mean depth of $16.5 \mathrm{~m}$ at full elevation ( $340.5 \mathrm{~m}$ above sea level), and the watershed encompasses $324,000 \mathrm{~km}^{2}$ [22]. The reservoir is oligotrophic (chlorophyll $a<1.5 \mu \mathrm{g} / \mathrm{L})$ and has high alkalinity ( 2-4 meq/L), aboveneutral $\mathrm{pH}(\sim 8.0)$, low water column DOC $(<1.0 \mathrm{mg} / \mathrm{L})$, and a small percentage of littoral zone and wetland area [22] (A. Groeger, unpublished data). The reservoir has three main 
Table 1. Site name, mean concentrations of total mercury, methylmercury, sediment, deep water physiochemical, and environmental factors ${ }^{\mathrm{a}}$

\begin{tabular}{|c|c|c|c|c|c|c|c|c|c|c|}
\hline \multirow[b]{2}{*}{ Site } & \multicolumn{4}{|c|}{ Sediments } & \multicolumn{3}{|c|}{ Pore water } & \multicolumn{3}{|c|}{ Deep water } \\
\hline & $\begin{array}{c}\mathrm{THg} \\
(\mathrm{ng} / \mathrm{g})\end{array}$ & $\begin{array}{l}\mathrm{MeHg} \\
(\mathrm{ng} / \mathrm{g})\end{array}$ & $\% \mathrm{OM}$ & $\begin{array}{c}\mathrm{C}: \mathrm{N} \\
\text { (molar) }\end{array}$ & $\begin{array}{c}\mathrm{SO}_{4}^{2-} \\
(\mathrm{mg} / \mathrm{L})\end{array}$ & $\begin{array}{c}\mathrm{Cl}^{-} \\
(\mathrm{mg} / \mathrm{L})\end{array}$ & $\begin{array}{c}\text { DOC } \\
(\mathrm{mg} / \mathrm{L})\end{array}$ & $\begin{array}{c}\text { Temp } \\
\left({ }^{\circ} \mathrm{C}\right)\end{array}$ & $\begin{array}{c}\mathrm{SO}_{4}^{2-} \\
(\mathrm{mg} / \mathrm{L})\end{array}$ & $\begin{array}{c}\mathrm{DOC} \\
(\mathrm{mg} / \mathrm{L})\end{array}$ \\
\hline $\mathrm{PR} 74^{\mathrm{b}}$ & 31.27 & 5.02 & 8.17 & 24.13 & 2.5 & 262 & 35.18 & 27.13 & & \\
\hline PR66 & $47.44 \pm 4.66$ & $0.67 \pm 0.17$ & $7.94 \pm 1.69$ & $22.0 \pm 1.79$ & $157.52 \pm 50.24$ & $123.40 \pm 27.20$ & $2.50 \pm 1.03$ & $25.49 \pm 1.42$ & $216-246$ & $1.57^{\mathrm{b}}$ \\
\hline RG65 & $40.39 \pm 1.82$ & $0.43 \pm 0.09$ & $8.28 \pm 1.70$ & $28.0 \pm 5.14$ & $230.00 \pm 56.51$ & $65.17 \pm 24.30$ & $4.37-5.00$ & $26.29 \pm 0.78$ & $152-342$ & $0.44^{\mathrm{b}}$ \\
\hline RG53 & $44.89 \pm 5.11$ & $0.60 \pm 0.17$ & $8.00 \pm 1.67$ & $21.2 \pm 2.01$ & $148.37 \pm 37.16$ & $134.25 \pm 8.45$ & $4.72 \pm 2.14$ & $26.36 \pm 0.93$ & $200-231$ & $0.44^{\mathrm{b}}$ \\
\hline RG45 & $44.73 \pm 1.50$ & $0.67 \pm 0.09$ & $9.11 \pm 1.51$ & $16.1 \pm 0.22$ & $113.6 \pm 16.09$ & $163.75 \pm 19.00$ & $4.22 \pm 1.90$ & $25.69 \pm 1.07$ & $220-244$ & $0.44^{\mathrm{b}}$ \\
\hline RG33 & $50.04 \pm 2.38$ & $0.58 \pm 0.09$ & $10.10 \pm 1.12$ & $16.9 \pm 1.21$ & $79.45 \pm 25.04$ & $150.75 \pm 2.39$ & $2.29 \pm 0.93$ & $20.88 \pm 0.97$ & $188-194$ & $0.44^{\mathrm{b}}$ \\
\hline RG26 & $44.53 \pm 0.68$ & $0.53 \pm 0.02$ & $10.38 \pm 1.20$ & $16.8 \pm 0.42$ & $74.75 \pm 16.57$ & $151.00 \pm 2.04$ & $3.57 \pm 1.97$ & $19.94 \pm 0.87$ & $184-198$ & $0.44^{\mathrm{b}}$ \\
\hline RG19 & $47.60 \pm 3.10$ & $0.57 \pm 0.05$ & $10.59 \pm 1.50$ & $17.6 \pm 0.29$ & $143.57 \pm 23.22$ & $151.50 \pm 3.32$ & $2.46 \pm 1.20$ & $19.51 \pm 0.85$ & $189-198$ & $0.44^{\mathrm{b}}$ \\
\hline RG12 & $49.15 \pm 1.27$ & $0.44 \pm 0.06$ & $10.15 \pm 1.70$ & $19.7 \pm 1.76$ & $133.50 \pm 29.20$ & $150.00 \pm 4.76$ & $2.24 \pm 0.90$ & $18.80 \pm 0.77$ & $191-194$ & $0.44^{\mathrm{b}}$ \\
\hline $\mathrm{RG} 1^{\mathrm{c}}$ & $41.21 \pm 2.58$ & $0.59 \pm 0.13$ & $10.57 \pm 1.57$ & $19.8 \pm 1.72$ & $128.85 \pm 15.20$ & $143.00 \pm 4.33$ & $2.57 \pm 1.49$ & $17.72 \pm 0.72$ & $179-196$ & $1.97^{\mathrm{b}}$ \\
\hline DR14 & $34.37 \pm 0.43$ & $0.93 \pm 0.18$ & $10.12 \pm 1.36$ & $25.1 \pm 1.73$ & $4.12 \pm 0.94$ & $123.25 \pm 3.59$ & $11.74 \pm 0.94$ & $18.29 \pm 0.64$ & $157-168$ & $0.44^{\mathrm{b}}$ \\
\hline DR18 & $34.81 \pm 1.48$ & $0.95 \pm 0.09$ & $10.77 \pm 1.43$ & $24.9 \pm 1.42$ & $22.87 \pm 20.38$ & $117.00 \pm 2.67$ & $10.51 \pm 1.57$ & $20.41 \pm 1.11$ & & \\
\hline DR21 & $36.52 \pm 3.39$ & $0.57 \pm 0.11$ & $10.10 \pm 1.07$ & $27.3 \pm 2.49$ & $12.04 \pm 4.86$ & $110.50 \pm 2.72$ & $12.12 \pm 2.04$ & $19.21 \pm 0.67$ & & \\
\hline DR25 & $29.53 \pm 1.57$ & $1.13 \pm 0.47$ & $10.40 \pm 0.99$ & $26.4 \pm 2.03$ & $8.95 \pm 4.50$ & $103.98 \pm 2.50$ & $4.79 \pm 2.86$ & $20.68 \pm 0.97$ & $40.8-117$ & $2.88^{\mathrm{b}}$ \\
\hline DR31 & $30.28 \pm 3.32$ & $2.94 \pm 0.35$ & $14.84 \pm 1.82$ & $25.7 \pm 1.05$ & $2.5^{\mathrm{d}}$ & $20.29 \pm 9.37$ & $14.94 \pm 3.59$ & $23.65 \pm 1.20$ & $14.5-17.6$ & $0.44^{\mathrm{b}}$ \\
\hline
\end{tabular}

${ }^{\text {a }}$ Values are mean \pm standard error. $\mathrm{THg}=$ sediment total $\mathrm{Hg} ; \mathrm{MeHg}=$ sediment methylmercury; \%OM = percent organic matter; $\mathrm{C}: \mathrm{N}=$ carbon:nitrogen ratio (molar); $\mathrm{SO}_{4}^{2-}=$ sulfates; $\mathrm{Cl}^{-}=$chlorides; $\mathrm{DOC}=$ dissolved organic carbon; Temp = temperature; site abbreviations are consistent with the text.

b Single sampling only.

${ }^{c}$ Site RG1 is closest to the dam at the confluence of the Devils River and Rio Grande arms of the Amistad International Reservoir (Texas, USA).

${ }^{\mathrm{d}}$ All samples were below the detection limit $\left(\mathrm{SO}_{4}^{2-}=5 \mathrm{mg} / \mathrm{L}, \mathrm{DOC}=0.88 \mathrm{mg} / \mathrm{L}\right)$.

surface water sources, the Rio Grande, the Pecos River, and the Devils River (Fig. 1), each characterized by unique physiochemical characteristics and degree of anthropogenic impact [14]. These rivers form two distinct arms: the Rio Grande arm, which receives flow from the Rio Grande, and Pecos River and the Devils River arm, which receives flow from the Devils River. The Rio Grande arm is characterized by higher $\mathrm{SO}_{4}^{2-}, \mathrm{Cl}^{-}$, and turbidity as well as a higher sedimentation rate because of the much larger watersheds and more intensive landuse of the Rio Grande and Pecos River compared with the Devils River watershed [16,23,24].

\section{Environmental variables, sediment, and bacterial collections}

Sediment physiochemical and environmental variables were sampled at 13 sites in the center of the inundated river channel of the Rio Grande and Devils River arms of the reservoir and at two sites in the inundated Pecos River portion of the reservoir, approximately 1 and $9 \mathrm{~km}$ upstream from the confluence with the Rio Grande (Table 1; Fig. 1). Sites are identified by twoletter abbreviations for river channel $(\mathrm{DR}=$ Devils River; $\mathrm{RG}=$ Rio Grande; $\mathrm{PR}=$ Pecos River), followed by a number corresponding to the approximate river channel distance (in river kilometers) upstream from the dam. At each site, sediment was collected once a month for four months (May through August 2007), except for site RG65, which was not sampled in June 2007, because of high flows. In addition, site PR74 was only sampled in August 2007. For quality assurance, $10 \%$ of the samples were collected as field replicate or split samples. These field quality assurance samples were included in the site averages for the study period.

At each site, temperature was determined using a Hydro$\mathrm{lab}^{\mathrm{TM}} \mathrm{H} 2 \mathrm{O}$ or DS5 multiprobe sonde (Hach Environmental). Sonde data were taken approximately $1 \mathrm{~m}$ above the sediment, and this deep-water temperature was used as a proxy for surficial sediment temperature. All glassware and utensils used in sampling were presoaked in $0.15 \mathrm{~N} \mathrm{HCl}$ for $24 \mathrm{~h}$, rinsed with Milli- $\mathrm{Q}^{\mathrm{TM}}$ water, and kept in clean plastic bags. Sediment samples were taken using either a Petite Ponar or an Ekman dredge. From each dredge, the top $5 \mathrm{~cm}$ of sediments was subsampled into acid-washed glass jars with polytetrafluoro- ethylene-lined lids for $\mathrm{THg}$ and $\mathrm{MeHg}$ analysis or into precleaned 50-ml centrifuge tubes for all other sediment analyses (percentage organic matter; $\mathrm{C}: \mathrm{N}$ ratio; and porewater $\mathrm{SO}_{4}^{2-}, \mathrm{Cl}^{-}$, and DOC concentrations). Sediment samples for analysis of $\mathrm{MeHg}$ were taken first and from the middle of each dredge using a new, clean plastic spoon at each site. All samples were stored on ice in the field. Samples for $\mathrm{Hg}$ and $\mathrm{MeHg}$ analysis were frozen at $-70^{\circ} \mathrm{C}$ immediately upon return to the laboratory (within $48 \mathrm{~h}$ ). All other samples were stored at $4^{\circ} \mathrm{C}$ for further processing and subsampling, which was performed within $24 \mathrm{~h}$ of return to the laboratory. Sediment pore water was extracted by centrifugation at $3,000 \mathrm{~g}$ for $1 \mathrm{~h}$ at $4{ }^{\circ} \mathrm{C}$. Supernatant was carefully removed and filtered through ashed Whatman GF/ $\mathrm{F}(0.7 \mu \mathrm{m}$ pore size $)$ filters for DOC analysis or was centrifuged again to remove any remaining particulate matter for $\mathrm{SO}_{4}^{2-}$ and $\mathrm{Cl}^{-}$analyses. Sediment subsamples for percentage organic matter and $\mathrm{C}: \mathrm{N}$ analyses were dried for $48 \mathrm{~h}$ at $50^{\circ} \mathrm{C}$ and homogenized with a ceramic mortar and pestle, which was cleaned with acetone between samples. Water from approximately $1 \mathrm{~m}$ above the sediment-water interface was collected at a limited number of sites (Table 1) during July and August 2007 for $\mathrm{SO}_{4}^{2-}$ and DOC analyses. This water was collected using an acrylic 4-L Kemmerer bottle, filtered through ashed Whatman GF/F filters, and analyzed by the same methods as porewater samples.

During the final month of the study (August 2007), sediment samples were taken to evaluate the presence and composition of the SRB community in surficial sediments $(<5 \mathrm{~cm})$, using two different methods. First, for qualitative detection of the major groups of SRB by polymerase chain reaction (PCR), $0.5 \mathrm{~g}$ of sediment was collected, stored on ice in the field, and frozen at $-80^{\circ} \mathrm{C}$ within $48 \mathrm{~h}$. In addition, we quantified the number of total bacteria and numbers of bacteria in known $\mathrm{Hg}$ methylating families (Desulfovibrionaceae and Desulfobacteriaceae) via fluorescent in situ hybridization (FISH). Approximately $0.75 \mathrm{~g}$ of sediment was fixed immediately in the field with $1 \mathrm{ml} 4 \%$ (w/v) paraformaldehyde/phosphate-buffered saline and stored at $4{ }^{\circ} \mathrm{C}$. Paraformaldehyde-fixed samples were washed in phosphate-buffered saline within $48 \mathrm{~h}$ and stored in $95 \%$ ethanol at $-20^{\circ} \mathrm{C}$ until use [25]. 


\section{Fish collections}

Fish were collected by the Texas Parks and Wildlife Department (TPWD, Austin, TX) and donated post-mortem after use in TPWD monitoring projects. Two separate collections of largemouth bass from the reservoir were used. The sampling referred to as small fish $(n=156)$ was collected in November 2007 using electrofishing methods. Fish were collected from five areas of the reservoir, and that information was used to assess the differences in $\mathrm{Hg}$ bioaccumulation. Two areas were on the Rio Grande arm, one was in the main Devils River arm, and two were side canyons in the Devils River arm (Fig. 1). It is assumed that all small fish were residents of the area in which they were collected, because multiple studies have concluded that largemouth bass have a $<5$-ha home range, even when habitat is abundant [26]. All largemouth bass in this collection were year 0 to 3 fish (TPWD, unpublished data), $6.5 \mathrm{~cm}$ to $30 \mathrm{~cm}$ in total length.

The sampling referred to as large fish was collected in April, 2007, by hook-and-line methods; among 138 received fish, a subset of individuals $(n=88)$ was analyzed for muscle $\mathrm{Hg}$ concentration. For this collection, no information was available on where in the reservoir the fish had been collected. All fish were $\geq 33.5 \mathrm{~cm}$ total length, with ages estimated to be $>$ three years (TPWD, unpublished data), and represent fish likely to be consumed by humans. Selection of individual fish for analysis was done to encompass the full size range of fish in the sample. For both collections, fish were placed on ice and transported to Texas State University-San Marcos within 24h, where they were weighed to the nearest $1 \mathrm{~g}$ and total length recorded to the nearest $0.5 \mathrm{~cm}$. Fish were then frozen at $-20^{\circ} \mathrm{C}$ until further processing.

\section{Mercury analyses}

All fish muscle samples and sediment samples from May were oven dried at $55^{\circ} \mathrm{C}$ for $48 \mathrm{~h}$ prior to $\mathrm{THg}$ analysis. All other sediment samples for $\mathrm{THg}$ analysis were freeze dried using a Labconco Freezone 6. Fish muscle samples were taken from fillets and, where possible, anteriodorsally. After drying, all $\mathrm{THg}$ samples were homogenized with a ceramic mortar and pestle, which was washed with reagent-grade acetone between samples. Total $\mathrm{Hg}$ for both fish tissue and sediment was determined using combustion atomic absorption spectrometry on a Milestone DMA-80. Calibration curves were generated using reference material from the National Research Council of Canada Institute for National Measurement Standards (PACS2, MESS-3, and DORM-2; http://www.nrc-cnrc.gc.ca/eng/services/inms/reference-materials.html\#data). Reference samples were analyzed every 10 samples, and duplicate samples were analyzed every 20 samples. Percentage recovery on reference samples was $103 \pm 4 \%$ (mean \pm 1 standard deviation, $n=37$ ) and mean percentage difference on duplicates was $1 \pm 3 \%$ $(n=20)$. Concentrations are presented on a wet weight basis for fish and on a dry weight basis for sediments. To convert the analyzed dry weight values for fish muscle to a wet weight value, fish from the first collection $(n=88)$ were weighed preand postdrying, and the mean ( \pm 1 standard deviation) of $79.6 \pm 1 \%$ water content was used as a conversion factor for all fish samples. It is assumed that in fish $\mathrm{THg} \sim \mathrm{MeHg}$, because $\geq 95 \%$ of the $\mathrm{Hg}$ in fish muscle is likely in $\mathrm{MeHg}$ form [27].

Methylmercury analysis on sediments was performed using two methods. A first group of samples $(n=24)$ was analyzed wet using $\mathrm{Hg}$-thiourea complex ion chromatography with online cold vapor generation and atomic fluorescence spectro- metric detection [28] at Quicksilver Scientific. For laboratory quality assurance, $10 \%$ of samples were run as laboratory duplicates and spikes. Spike recovery was 96 to $99 \%$, and laboratory duplicate differences were $<4 \%$. Recovery on reference material (BCR 463; http://www.irmm.jrc.be/html/ reference_materials_catalogue/catalogue/certificates_and_ reports/BCR-463_cert.pdf) was $97 \%$. Concentrations were corrected to a dry weight equivalent, and the method detection limit was approximately $0.12 \mathrm{ng} / \mathrm{g}$ (dry wt). The remaining sediment samples $(n=33)$ were analyzed after freeze drying by U.S. Environmental Protection Agency (U.S. EPA) Method 1630 [29]. For quality assurance, method blanks, estuarine sediment reference material (ERM-CC580; http://www.irmm.jrc.be/ $\mathrm{html} /$ reference_materials_catalogue/catalogue/certificates_ and_reports/ERM-CC580_cert.pdf), or sample duplicates were run every 10 samples. Mean percentage recovery on reference samples was $67 \pm 10 \%(n=4)$, and mean percentage difference on laboratory duplicates was $4 \pm 26 \%(n=5)$. To crosscalibrate between the two sediment $\mathrm{MeHg}$ analysis methods, five samples were split and analyzed with both methods. Samples analyzed by U.S. EPA 1630 had significantly lower $\mathrm{MeHg}$ than the companion samples analyzed at Quicksilver Scientific (mean difference $0.23 \pm 0.09 \mathrm{ng} \mathrm{MeHg} / \mathrm{g}$; paired $t$ test, $t=5.616, p=0.005)$. Thus, we adjusted all sediment $\mathrm{MeHg}$ estimates by adding $0.23 \mathrm{ng}$ to the U.S. EPA 1630 analyzed value.

\section{Molecular analysis and bacterial community estimates}

For qualitative detection of major groups of SRB, DNA was extracted from sediment using the methods of Welsh et al. [30]. Polymerase chain reaction amplification was performed on the DNA extracts from each site, using primer sets of Amann et al. [31] and Daly et al. [32]. Reactions and amplifications, including negative controls, were carried out using a hot-start protocol [32]. Sediment DNA extract from Harrier Meadow (New Jersey, USA), which was confirmed to have SRB DNA [30], was used as a positive control for the SRB family reactions. No controls were used in the more detailed group reactions. For quality control, subsamples from site RG45 were split, and analyses were run on both splits. Field replicates were taken at site DR25. Results between the splits and the replicates were identical for all molecular analyses except for those targeting Desulfobacter. At site DR25, there was a weak signal indicating the presence of Desulfobacter in the first sample, but no detection in the replicate sample. This was considered a positive detection, as direct PCR is a qualitative technique. Even groups that were not detected may be present, but at low enough numbers not to be considered a substantial part of the SRB community.

Fluorescent in situ hybridization was used to quantify sediment total bacteria and SRB communities numerically [25,33]. All microbial cells were stained with the DNA intercalating dye 4',6-diamidino-2-phenylindole (DAPI). Cy3-labeled probes EUB338, EUB II, and EUB III were used in combination to detect all bacteria [34], and probes SRB385 and SRB-Db were used individually to detect members of the families Desulfovibrionaceae and Desulfobacteriaceae, respectively [33]. For slide application, $10 \mu \mathrm{l}$ sample was dispersed sequentially in $0.01 \%$ sodium pyrophosphate to a $1 \%$ sample concentration. To improve cell permeability, samples were treated with $20 \mu 110 \%$ dimethylsulfoxide for $1 \mathrm{~h}$ at room temperature [35], rinsed with distilled water, allowed to dry, and further treated with $20 \mu 11 \%$ lysozyme for $30 \mathrm{~min}$ at room temperature [25]. To hybridize the probes, $9 \mu$ l hybridization buffer, $1 \mu$ l of the probe or probe mix 
(50 ng), and $1 \mu \mathrm{l}$ of DAPI solution (200 ng) were applied to each sample and incubated at $42^{\circ} \mathrm{C}$ for $16 \mathrm{~h}$ in a humid chamber. Detailed information on the molecular primers and probes used in the present study and the conditions used for amplification and hybridization are presented in Supplemental Data, Table S1.

For counting, slides were mounted with Citifluor ${ }^{\mathrm{TM}}$ AF1 solution and examined with a Nikon Eclipse 80i microscope, fitted for epifluorescence microscopy with a mercury lamp (Nikon; X-Cite ${ }^{\mathrm{TM}} 120$ ) and two filter cubes, UV-2E/C (Nikon; EX340-380, DM400, BA4435-485 for DAPI detection) and Cy3 HYQ (Nikon; EX535/50, DM565, BA610/75 for Cy3 detection). For each site, 30 to 50 fields covering $0.01 \mathrm{~mm}^{2}$ were selected haphazardly from two to five slide wells hybridized with each probe, and cell counts were converted to the average cells per dry gram of sediment. Sites RG65 and PR66 could not be counted because extremely high autofluorescence of particles and low bacterial numbers made accurate counts impossible.

\section{Physiochemical analyses}

Percentage organic matter of sediments was determined by loss-on-ignition combustion at $500^{\circ} \mathrm{C}$ for $4 \mathrm{~h}$ after drying of approximately $4 \mathrm{~g}$ wet samples at $55^{\circ} \mathrm{C}$ for $48 \mathrm{~h}$. Sediment total carbon and nitrogen content were determined on dried sediment by gas chromatography using a Thermo Electron Flash EA 1112 NC soil analyzer (Thermo Fisher Scientific), and data are presented as the molar $\mathrm{C}: \mathrm{N}$ ratio. Porewater $\mathrm{SO}_{4}^{2-}$ and $\mathrm{Cl}^{-}$ concentrations were determined by ion chromatography on a Lachat QuickChem 8500 (Hach Company). Concentration of DOC was determined using high-temperature catalytic combustion on a Shimadzu TOC- $\mathrm{V}_{\mathrm{CSH}}$ total organic carbon analyzer (Shimadzu North America/Shimadzu Scientific Instruments). For statistical analysis, a value of half the detection limit was used when samples for physiochemical parameters of porewater $\mathrm{SO}_{4}^{2-}$ and deepwater DOC were below detection. All other physiochemical parameters were above the detection limit for all samples.

\section{Statistical methods}

To determine whether significant differences in sediment $\mathrm{THg}$ and $\mathrm{MeHg}$ concentrations between the sampling months or reservoir arms existed, data were analyzed using a mixed-effect, repeated-measures analysis of variance (rm-ANOVA). Sites were designated as the random factor, nested within month, and grouped by reservoir arm. This technique allowed us to utilize the unbalanced data set, determine how much variability in sediment $\mathrm{Hg}$ was explained by the sampling sites, and assess the spatial patterns of $\mathrm{THg}$ and $\mathrm{MeHg}$ concentrations in a fashion roughly equivalent to that used for the small fish (see below). Sites sampled at least three times during the study period were included in the rm-ANOVA; however, site RG1 was excluded from this analysis because it is located in the thalweg at the confluence of the Rio Grande and Devils River arms and is not independent from either arm. Total $\mathrm{Hg}$ data did not need any transformations to meet the assumption of normality, but $\mathrm{MeHg}$ and the proportion of $\mathrm{THg}$ as $\mathrm{MeHg}(\mathrm{MeHg}$ : $\mathrm{THg}$ ) data required Box-Cox power transformations to correct for substantial skew. There was no significant sampling month $\times$ arm interaction for $\mathrm{THg}, \mathrm{MeHg}$, or $\mathrm{MeHg}$ : $\mathrm{THg}$ (all $p \geq 0.153$ ).

To determine whether sediment $\mathrm{THg}$ and $\mathrm{MeHg}$ concentrations could be related to spatial differences in physiochemical and microbiological parameters among sites, principal components analysis (PCA) was used to summarize variation in the data set for sediment parameters. Sites RG1 and PR74 were included in this analysis because the pattern of correlations among all of the measured variables was of primary interest. Because DOC was sampled only from June through August, 2007, and there was no distinct seasonal trend in concentrations, the mean value for each site was used as the site value for May in the PCA. This allowed us to utilize the data with an estimation of the May 2007 DOC values that minimized any influence on the PCA loadings [36]. The SRB detection matrix for PCR and FISH analysis from August 2007 was applied to May through June because bacteria were sampled once, and it was assumed that the sediment samples likely integrate microbial communities across relatively longer time scales (i.e., months). However, because FISH analysis was not possible at sites RG65 and PR66, these sites were excluded from the PCA. With these caveats and with the mix of continuous and binomial data, PCA in this case is a descriptive tool used to elucidate the relationships present in the data, not as a method to test relationships. All data were $\mathrm{z}$-score transformed prior to analysis, and PCA was run using a correlation matrix [36].

The data from the two collections of largemouth bass were analyzed separately using two different methods. The small fish were used to assess the spatial patterns of bioaccumulation of $\mathrm{Hg}$ into largemouth bass from different areas of the reservoir using the polynomial regression analysis method of Tremblay et al. [37]. The resulting model was used to predict $\mathrm{Hg}$ concentrations (mean $\pm 95 \%$ confidence intervals) at a standard length of $18.5 \mathrm{~cm}$ for each lake area. This length was chosen because it was the mean length for this entire collection. Data were first checked for normality and homoscedasticity using scatterplots and residual plots, and a square root transformation was most appropriate for meeting the assumptions of the analysis. The Tremblay et al. [37] method allows for variation in the slopes and/or form of the length-muscle $\mathrm{Hg}$ relationship between areas or time periods, a situation that violates the assumptions of traditional analysis of covariance [37]. Because the large fish lacked any location data, they were used only to assess the concentration of $\mathrm{Hg}$ in largemouth bass likely to be consumed by humans and were analyzed by using lengthmuscle $\mathrm{Hg}$ correlation analysis. All statistical analyses were performed in the JMP statistical package (ver 8.0; SAS Institute).

\section{RESULTS}

\section{Sediment $\mathrm{Hg}$ and $\mathrm{MeHg}$}

All sediment samples analyzed for $\mathrm{THg}$ and $\mathrm{MeHg}$ were above detection limits. Sediment $\mathrm{THg}$ concentrations were significantly different between the reservoir arms $\left(f_{1,9.66}=\right.$ 58.99, $p<0.0001)$ : the Rio Grande arm had higher levels of sediment THg than the Devils River arm (46.2 $\pm 1.07 \mathrm{ng} / \mathrm{g}$ and $33.01 \pm 1.33 \mathrm{ng} / \mathrm{g}$, mean \pm S.E.; Fig. 2a). There was no effect of sampling month $\left(f_{3,31.01}=0.16, p=0.923\right)$. Variance partitioning for the random effect of site accounted for $3.7 \%$ of the remaining variation in sediment $\mathrm{THg}$ concentration. This result suggests that variation between sites within each arm accounted for a relatively small proportion of the variability in sediment $\mathrm{THg}$ concentrations.

Sediment $\mathrm{MeHg}$ concentrations were significantly different between the reservoir arms $\left(f_{1,10.9}=10.19, p=0.0087\right)$ : the Devils River arm had higher levels of sediment $\mathrm{MeHg}$ than the Rio Grande arm $(0.84 \pm 0.19 \mathrm{ng} / \mathrm{g}$ and $0.51 \pm 0.15 \mathrm{ng} / \mathrm{g}$; Fig. 2a). There was a significant effect of sampling month in the rm-ANOVA $\left(f_{3,32.1}=3.19, p=0.0364\right)$, but post hoc 

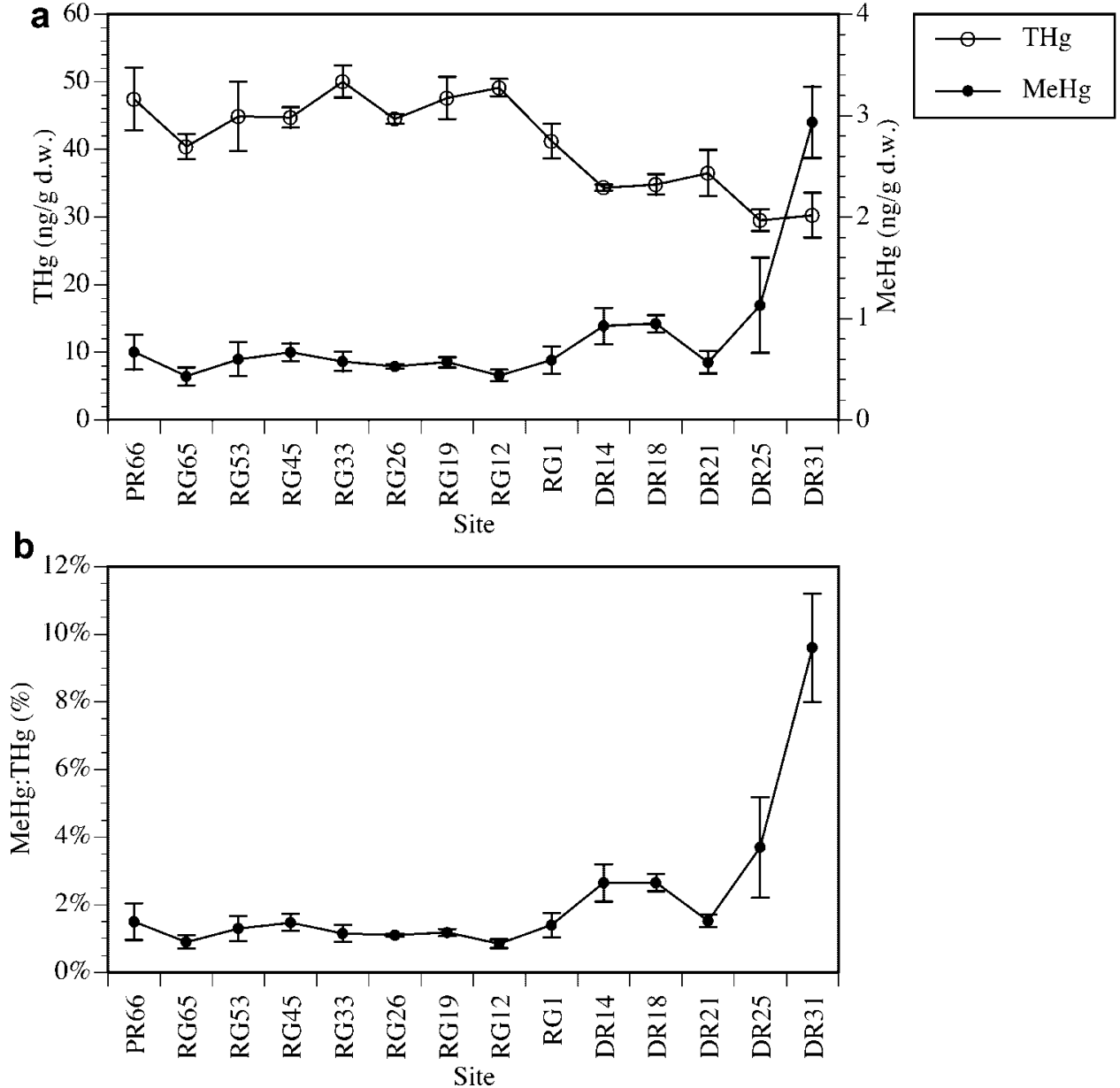

Fig. 2. (a) Concentrations of total mercury ( $\mathrm{THg}$ ) and methylmercury ( $\mathrm{MeHg}$ ) (mean \pm standard error) at sediment sampling sites in Amistad International Reservoir in Texas, USA. Left axis is for THg; right axis is for MeHg. Note different scales. (b) Proportion of THg as MeHg (mean percentage \pm standard error) at each sediment sampling site. Site abbreviations are consistent with Table 1 and Figure 1.

Tukey's honestly significant difference $(\alpha=0.05)$ tests did not show significant differences between sampling months (all $p>0.0625$ ). In contrast to the results for sediment THg, variance partitioning for the random effect of site accounted for $33.6 \%$ of the remaining variation in sediment $\mathrm{MeHg}$ concentration, suggesting substantial variation in sediment $\mathrm{MeHg}$ between sites within each arm. This result indicates that in addition to significant differences in sediment $\mathrm{MeHg}$ between arms of the reservoir, sites within the arms had consistent spatial patterns of $\mathrm{MeHg}$ concentrations.

The proportion of $\mathrm{THg}$ as $\mathrm{MeHg}$, a common measure of net $\mathrm{MeHg}$ production and relative bioavailability of $\mathrm{Hg}[11,38]$, also exhibited significant spatial variation in the reservoir. Sediment $\mathrm{MeHg}: \mathrm{THg}$ was significantly different between the reservoir arms $\left(f_{1,11}=26.6, p<0.0003\right)$ : the Devils River arm had a higher MeHg:THg (presented as a percentage) than the Rio Grande arm $(4.0 \% \pm 0.9 \%$ and $1.2 \% \pm 0.7 \%$; Fig. $2 b)$. There was no effect of sampling month $\left(f_{3,32.25}=1.8\right.$, $p=0.153$ ). Variance partitioning for the random effect of site accounted for $23.3 \%$ of the remaining variation in sediment $\mathrm{MeHg}: \mathrm{THg}$, suggesting variation in sediment $\mathrm{MeHg}: \mathrm{THg}$ between sites within each arm. As with sediment $\mathrm{MeHg}$, this result indicates that in addition to significant differences in sediment $\mathrm{MeHg}: \mathrm{THg}$ between arms of the reservoir, sites within the arms had relatively consistent spatial patterns of $\mathrm{MeHg}: \mathrm{THg}$.

\section{Bacterial communities}

Polymerase chain reaction amplicons indicating the presence of members of the families Desulfovibrionaceae and Desulfobacteriaceae were found at all sites (Table 2). The PCR amplicons representing members of Desulfobulbus were detected only at site PR74, whereas those representing Desulfobacter were detected at site PR74 as well as at three Devils River arm sites (DR21, DR25, and DR31). PCR amplicons indicated the presence of Desulfovibrio-Desulfomicrobium at sites RG1, RG12, RG19 and at all of the Devils River arm sites. Polymerase chain reaction did not produce amplicons indicating the presence of Desulfotomaculum, Desulfobacterium, and Desulfococcus-Desulfonema-Desulfosarcina at any sites.

Bacterial community abundance estimates using FISH varied by more than an order of magnitude among sites in AIR (Table 3). The highest numbers of total microbial and total bacterial cells were in the lower and middle Rio Grande arm, with site RG26 having the highest numbers of both $(293.0 \pm 8.5$ and $228.2 \pm 8.4 \times 10^{8}$ cells [g sediment, dry $\mathrm{wt}^{-1}$, respectively; mean \pm standard error). Site RG26 also had the highest numbers of Desulfovibrionaceae and Desulfobacteriaceae cells $\left(22.0 \pm 2.8\right.$ and $35.5 \pm 4.1 \times 10^{8}$ cells [g sediment, dry wt] ${ }^{-1}$, respectively), making up $7.9 \pm 0.7 \%$ and $12.2 \pm 1.3 \%$ of the total microbial cells at that site. For Desulfobacteriaceae cells, this was substantially higher than anywhere else in the reservoir. 
Table 2. Polymerase chain reaction (PCR) detections of sulfate reducing bacteria and subgroups ${ }^{\mathrm{a}}$

\begin{tabular}{|c|c|c|c|c|c|c|c|c|c|c|c|c|c|c|c|}
\hline Bacterial group & PR74 & PR66 & RG65 & RG53 & RG45 & RG33 & RG26 & RG19 & RG12 & $\mathrm{RG} 1^{\mathrm{b}}$ & DR14 & DR18 & DR21 & DR25 & DR31 \\
\hline SRB & + & + & + & + & + & + & + & + & + & + & + & + & + & + & + \\
\hline 1. DFM & - & - & - & - & - & - & - & - & - & - & - & - & - & - & - \\
\hline 2. DBB & + & - & - & - & - & - & - & - & - & - & - & - & - & - & - \\
\hline 3. DBM & - & - & - & - & - & - & - & - & - & - & - & - & - & - & - \\
\hline 4. DSB & + & - & - & - & - & - & - & - & - & - & - & - & + & + & + \\
\hline 5. DCC-DNM-DSS & - & - & - & - & - & - & - & - & - & - & - & - & - & - & - \\
\hline 6. DSV-DMB & - & - & - & - & - & - & - & + & + & + & + & + & + & + & + \\
\hline
\end{tabular}

${ }^{\mathrm{a}}+=$ positive detection of amplification product; $-=$ no visible band of PCR product on agarose gel; site abbreviations are consistent with Table 1. SRB $=$ all $\mathrm{SRB}$ in Desulfovibrionaceae and Desulfobacteriaceae families; DFM = Desulfotomaculum; DBB $=$ Desulfobulbus; DBM $=$ Desulfobacterium; DSB = Desulfobacter; DCC-DNM-DSS = Desulfococcus-Desulfonema-Desulfosarcina; DSV-DMB = Desulfovibrio-Desulfomicrobium

${ }^{\mathrm{b}}$ Site RG1 is closest to the dam at the confluence of the Devils River and Rio Grande arms of the Amistad International Reservoir (Texas, USA).

Across the reservoir, Desulfovibrionaceae cells made up $5.5 \pm 0.8 \%$ of the total microbial cells, and Desulfobacteriaceae cells accounted for $5.9 \pm 0.9 \%$ of the total microbial community.

\section{Relationship among $\mathrm{Hg}, \mathrm{MeHg}$, physiochemistry, and SRB}

The first three axes of the overall PCA model explained $70.9 \%$ of the variance in the data. The PCA indicated that the reservoir can be separated into three regions by unique biogeochemistry. Along PCA I and II there was separation of sites located in the Devils River arm, upper Rio Grande arm, and lower Rio Grande arm of the reservoir (Fig. 3a). Principal components axis I explained $34.7 \%$ of the variation in the data and was largely influenced by chemical components. Sites in the Devils River arm all had generally a higher C:N ratio, presence of Desulfobacter, and higher porewater DOC and $\mathrm{MeHg}$ concentrations, whereas sites in the Rio Grande arm had higher porewater $\mathrm{SO}_{4}^{2-}$ and $\mathrm{THg}$ concentrations (Table 1). Principal components axis II explained $20.3 \%$ of the variation in the data and was largely influenced by microbial components. Sites in the lower and middle reaches of the Rio Grande arm had higher numbers of bacteria, and sites in the upper Rio Grande arm were typically warmer over the sampling period (Table 1). Site RG1 was consistently located at the origin of both axes, indicating that it represents an area of consistent mixing between the two arms. Principal components axis III explained $15.9 \%$ of the variance in the data; however, there was no apparent ordination of sites according to spatial locations within the reservoir; therefore, PCA III is not depicted in Figure 3. The eigenvector for $\mathrm{MeHg}$ along PCA I and II aligns with that for porewater
DOC and is opposite those for $\mathrm{THg}$ and porewater $\mathrm{SO}_{4}^{2-}$, showing that $\mathrm{MeHg}$ has a positive correlation with DOC and an inverse relationship with $\mathrm{THg}$ and porewater $\mathrm{SO}_{4}^{2-}$ in the sediments of AIR (Fig. 3b). All three eigenvectors for bacterial abundance are largely orthogonal to $\mathrm{MeHg}$ and $\mathrm{THg}$, suggesting no relationship with these variables.

\section{Mercury in largemouth bass}

At the standardized length of $18.5 \mathrm{~cm}$, which is presumably year 0 to 1 for largemouth bass (TPWD, unpublished data), both Rio Grande arm areas had significantly lower mean muscle $\mathrm{Hg}$ concentrations (both $0.08 \pm 0.009 \mathrm{mg} / \mathrm{kg}$, predicted mean $\pm 95 \%$ confidence interval) than either the San Pedro Canyon or the Devils River area $(0.13 \pm 0.014$ and $0.11 \pm 0.014 \mathrm{mg} / \mathrm{kg}$, respectively; Fig. 4). Muscle Hg concentration in the large fish was correlated with fish size (Fig. 5). The mean for this collection was $0.51 \mathrm{mg} / \mathrm{kg}$. Approximately $77 \%$ of the largemouth bass in this collection exhibited $\mathrm{Hg}$ concentrations higher than the $0.3 \mathrm{mg} / \mathrm{kg}$ U.S. EPA recommended human consumption advisory level. Even largemouth bass at the minimum legal sport fishing limit $(35.5 \mathrm{~cm})$ exceeded the U.S. EPA guideline.

\section{DISCUSSION}

\section{Sediment $\mathrm{Hg}$ and $\mathrm{MeHg}$}

The spatial patterns in $\mathrm{THg}$ concentrations show that there is higher $\mathrm{THg}$ loading to the Rio Grande arm of the reservoir. These relatively elevated $\mathrm{Hg}$ concentrations could be caused by atmospherically deposited $\mathrm{Hg}$ moving through the larger water-

Table 3. Bacterial community abundance estimates and fluorescent in situ hybridization (FISH) probe counts ${ }^{\mathrm{a}}$

\begin{tabular}{|c|c|c|c|c|c|c|c|}
\hline Site & Total microbes $\left(\times 10^{8}\right)$ & EUB338 $\left(\times 10^{8}\right)$ & EUB338 (\%) & $\mathrm{SRB}\left(\times 10^{8}\right)$ & SRB $(\%)$ & SRB-Db $\left(\times 10^{8}\right)$ & SRB-Db (\%) \\
\hline PR74 & $180.7 \pm 12.3$ & $128.1 \pm 6.8$ & $70.9 \pm 3.2$ & $9.3 \pm 0.8$ & $7.3 \pm 0.6$ & $7.9 \pm 0.8$ & $7.1 \pm 0.7$ \\
\hline RG53 & $76.8 \pm 2.3$ & $56.0 \pm 3.2$ & $72.9 \pm 3.4$ & $2.3 \pm 1.0$ & $3.8 \pm 1.2$ & $0.7 \pm 0.2$ & $1.1 \pm 0.4$ \\
\hline RG45 & $96.6 \pm 6.3$ & $84.5 \pm 5.8$ & $87.5 \pm 2.8$ & $3.0 \pm 0.6$ & $3.8 \pm 0.7$ & $1.8 \pm 0.4$ & $2.2 \pm 0.7$ \\
\hline RG33 & $273.9 \pm 8.5$ & $228.2 \pm 8.4$ & $83.3 \pm 2.0$ & $6.9 \pm 1.0$ & $3.5 \pm 0.5$ & $7.1 \pm 1.2$ & $3.2 \pm 0.6$ \\
\hline RG26 & $293.0 \pm 11.1$ & $258.5 \pm 8.0$ & $88.2 \pm 1.8$ & $22.0 \pm 2.8$ & $7.9 \pm 0.7$ & $35.5 \pm 4.1$ & $12.2 \pm 1.3$ \\
\hline RG19 & $269.9 \pm 23.1$ & $208.2 \pm 17.0$ & $77.1 \pm 2.4$ & $13.5 \pm 1.3$ & $5.8 \pm 0.6$ & $13.1 \pm 1.5$ & $5.7 \pm 0.9$ \\
\hline RG12 & $285.9 \pm 14.8$ & $219.8 \pm 10.7$ & $76.9 \pm 2.6$ & $16.9 \pm 1.4$ & $7.1 \pm 0.6$ & $20.7 \pm 1.7$ & $7.4 \pm 0.5$ \\
\hline $\mathrm{RG} 1^{\mathrm{b}}$ & $171.6 \pm 11.0$ & $102.7 \pm 7.9$ & $59.8 \pm 2.1$ & $7.5 \pm 1.0$ & $4.7 \pm 0.9$ & $5.7 \pm 0.9$ & $3.7 \pm 0.7$ \\
\hline DR14 & $139.1 \pm 9.3$ & $74.5 \pm 5.1$ & $53.6 \pm 2.0$ & $4.6 \pm 0.8$ & $3.5 \pm 0.5$ & $6.5 \pm 1.1$ & $4.5 \pm 0.8$ \\
\hline DR18 & $185.2 \pm 7.8$ & $118.7 \pm 4.7$ & $64.1 \pm 2.4$ & $6.3 \pm 0.8$ & $4.1 \pm 0.4$ & $14.0 \pm 1.2$ & $8.5 \pm 2.4$ \\
\hline DR21 & $147.1 \pm 11.8$ & $113.9 \pm 5.1$ & $77.4 \pm 3.1$ & $5.5 \pm 0.9$ & $4.5 \pm 0.8$ & $9.1 \pm 1.2$ & $7.5 \pm 1.4$ \\
\hline DR25 & $209.2 \pm 12.5$ & $137.2 \pm 7.4$ & $65.6 \pm 2.7$ & $9.0 \pm 1.2$ & $4.7 \pm 0.5$ & $9.0 \pm 0.8$ & $4.7 \pm 0.6$ \\
\hline DR31 & $145.2 \pm 9.1$ & $103.1 \pm 4.7$ & $71.0 \pm 3.3$ & $8.4 \pm 1.3$ & $5.5 \pm 0.8$ & $11.4 \pm 1.1$ & $8.7 \pm 1.0$ \\
\hline
\end{tabular}

${ }^{a}$ Counts are estimated number of bacteria per dry gram of soil \pm standard error; percentages are based on $4^{\prime}, 6$-diamidino-2-phenylindole (DAPI) estimations of the total microbial community; site abbreviations are consistent with Table 1; EUB338 =all bacteria; SRB $=$ Desulfovibrionaceae; SRB-Db= Desulfobacteriaceae.

b Site RG1 is closest to the dam at the confluence of the Devils River and Rio Grande arms of the Amistad International Reservoir (Texas, USA). 
SRB-Db (0.43)

SRB (0.41)

Bact. (0.33)

DSV (0.33)

$\% \mathrm{OM}(0.30)$

Temp. (-0.44)

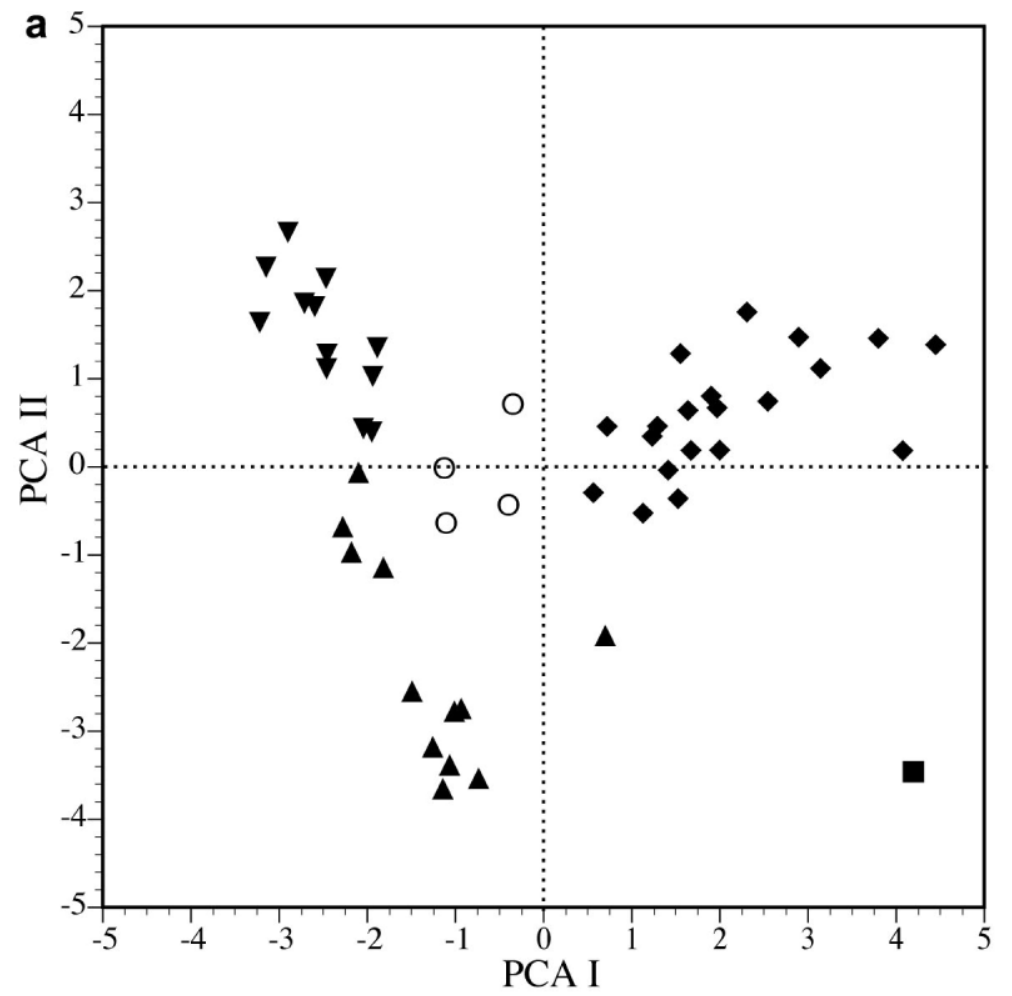

THg (-0.37)

$\mathrm{C}: \mathrm{N}(0.36)$

$\mathrm{SO}_{4}^{2-}(-0.32)$

DSB (0.35)

$\operatorname{DOC}(0.35)$

$\mathrm{MeHg}(0.30)$

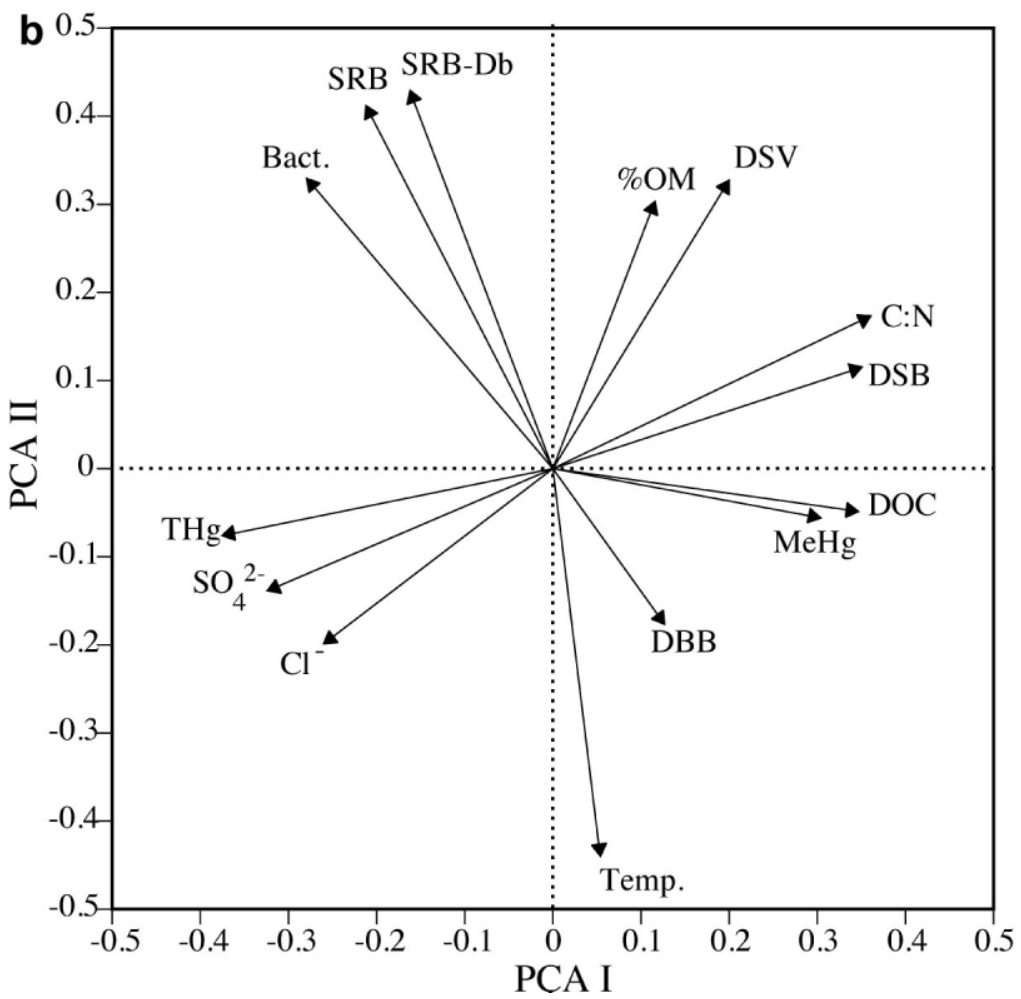

Fig. 3. Results of principal components analysis (PCA), showing axes I and II. (a) The site scores for the study period are shown as well as the major variables associated with each axis. $\boldsymbol{\nabla}=$ lower Rio Grande arm sites (RG12, RG19, RG26); $\boldsymbol{\Delta}=$ upper Rio Grande arm sites (RG33, RG45, RG53); $O=$ site RG1; $\checkmark=$ Devils River arm sites; $\mathbf{\square}=$ site PR74; THg = sediment total $\mathrm{Hg} ; \mathrm{MeHg}=$ sediment methylmercury concentration; DOC $=$ porewater dissolved organic carbon concentration; $\mathrm{C}: \mathrm{N}=$ sediment carbon:nitrogen (molar), $\% \mathrm{OM}=$ sediment percentage organic matter; Temp $=$ deep water temperature; $\mathrm{SO}_{4}^{2-}=$ sediment porewater sulfate concentration; $\mathrm{Cl}^{-}=$sediment porewater chloride concentration; DSB = positive detection of Desulfobacter; DSV $=$positive detection of Desulfovibrio-Desulfomicrobium; $\mathrm{DBB}=$ positive detection of Desulfobulbus; $\mathrm{SRB}=$ Desulfovibrionaceae abundance; $\mathrm{SRB}-\mathrm{Db}=\mathrm{Desulfobacteriaceae}$ abundance; Bact. $=$ total bacterial abundance. (b) The eigenvectors depicting the correlation between the analyzed variables. Abbreviations are consistent with (a). 


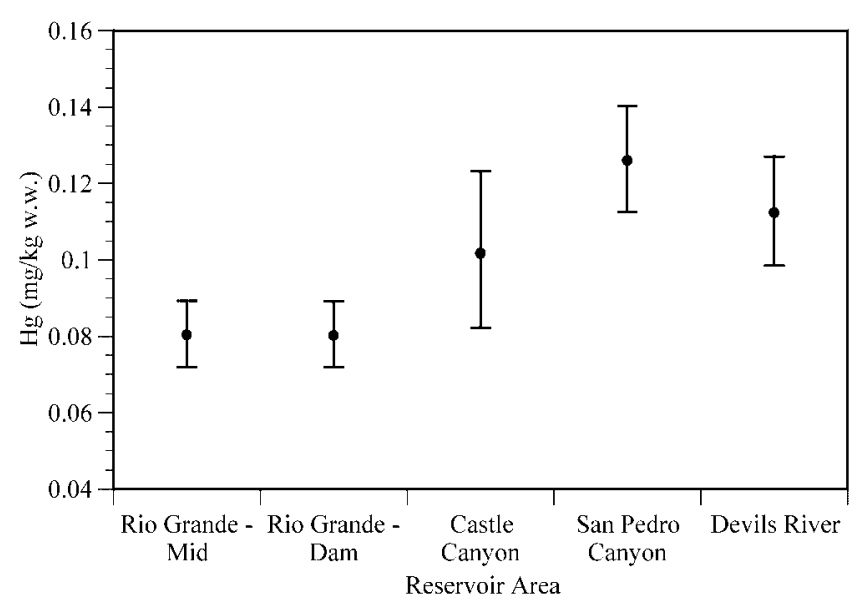

Fig. 4. Results of polynomial regression on the collection of small Micropterus salmoides showing predicted mean muscle $\mathrm{Hg}$ concentration $\pm 95 \%$ confidence interval at the standardized length of $18.5 \mathrm{~cm}$ for each reservoir area.

shed, movement of naturally $\mathrm{Hg}$-containing sediments from upstream areas with geologic sources of $\mathrm{Hg}$, or a combination of the two processes. The watershed for the Rio Grande arm above AIR is $300,200 \mathrm{~km}^{2}$ (including the $91,100-\mathrm{km}^{2}$ Pecos River drainage), and the drainage basin for the Devils River arm is substantially smaller at $10,250 \mathrm{~km}^{2}$ [23]. It is well established that larger watersheds have higher sediment export rates [24]. Additionally, $\mathrm{Hg}$ mining in the Rio Grande watershed occurred in the Terlingua district, approximately 250 river km upstream. The Terlingua district was the third largest mercury mining district in the United States, but the mines have been inactive since 1973 [17]. Although Gray et al. [17] concluded that little movement of contaminated sediments occurred from the Terlingua mining district, flash flood events are a common characteristic of arid stream systems [39], and river $\mathrm{Hg}$ sediment concentrations in both the Rio Grande and Pecos River watersheds have occasionally surpassed the Texas Commission on Environmental Quality screening level of $100 \mathrm{ng} / \mathrm{g}$ (dry wt)
$[13,40]$. Consequently, some movement of $\mathrm{Hg}$ may occur in sediments during high pulse flows into the main stem of the Rio Grande.

The higher levels of $\mathrm{MeHg}$ in the Devils River arm suggest two possible and potentially complimentary scenarios. First, it is possible that conditions in the Devils River arm of the reservoir are more favorable to methylation; the production of $\mathrm{MeHg}$ is thought to be primarily an in situ process [3] and thus driven by local conditions. Even within the different arms, the uppermost sites in the Devils River arm (sites DR25 and DR31) and in the uppermost Pecos River (site PR74) have substantially higher $\mathrm{MeHg}$ than other sites within these arms. The sediments in the Devils River arm and at site PR74 have generally higher organic matter and porewater DOC and lower porewater $\mathrm{SO}_{4}^{2-}$ concentrations (Table 1), conditions thought to enhance $\mathrm{Hg}$ methylation $[1,4]$. Second, it is possible that the source of inorganic $\mathrm{Hg}$ to the Devils River arm of the reservoir is in a form that is more easily transformed into $\mathrm{MeHg}$. Inorganic $\mathrm{Hg}$ from atmospheric sources is likely to be more labile and bioavailable for methylation (primarily as $\mathrm{Hg}(\mathrm{II})$ ) than inorganic $\mathrm{Hg}$ from geologic and $\mathrm{Hg}$ mining-related sources (often in $\mathrm{HgS}$ form as cinnabar or metacinnabar [38]). Mercury in the Devils River arm is likely to be primarily atmospherically derived, because geologic sources of $\mathrm{Hg}$ in the Devils River watershed are unknown, and it is unlikely that they would be substantial, because bedrock in the drainage is primarily Cretaceous limestone with no volcanic intrusions [41]. However, it is likely that $\mathrm{Hg}$ from natural geologic and past mining activities is a substantial portion of the total $\mathrm{Hg}$ loading to the Rio Grande arm. Additionally, as watershed size increases, a decrease in transport efficiency of $\mathrm{Hg}$ that has been deposited on the landscape is seen (presumably atmospherically derived $\mathrm{Hg}$ ) as well as a higher proportion of $\mathrm{Hg}$ being associated with a less bioavailable particulate fraction [3]. Again, the watershed Rio Grande arm of AIR is approximately 30 times larger than that of the Devils River arm. Assuming that the atmospheric input rate to the reservoir surface is equal between the two arms and that the atmospherically deposited portion of the total $\mathrm{Hg}$ load in the Rio Grande arm is diluted because of high sedimentation [16] of material that contains refractory $\mathrm{Hg}$, the

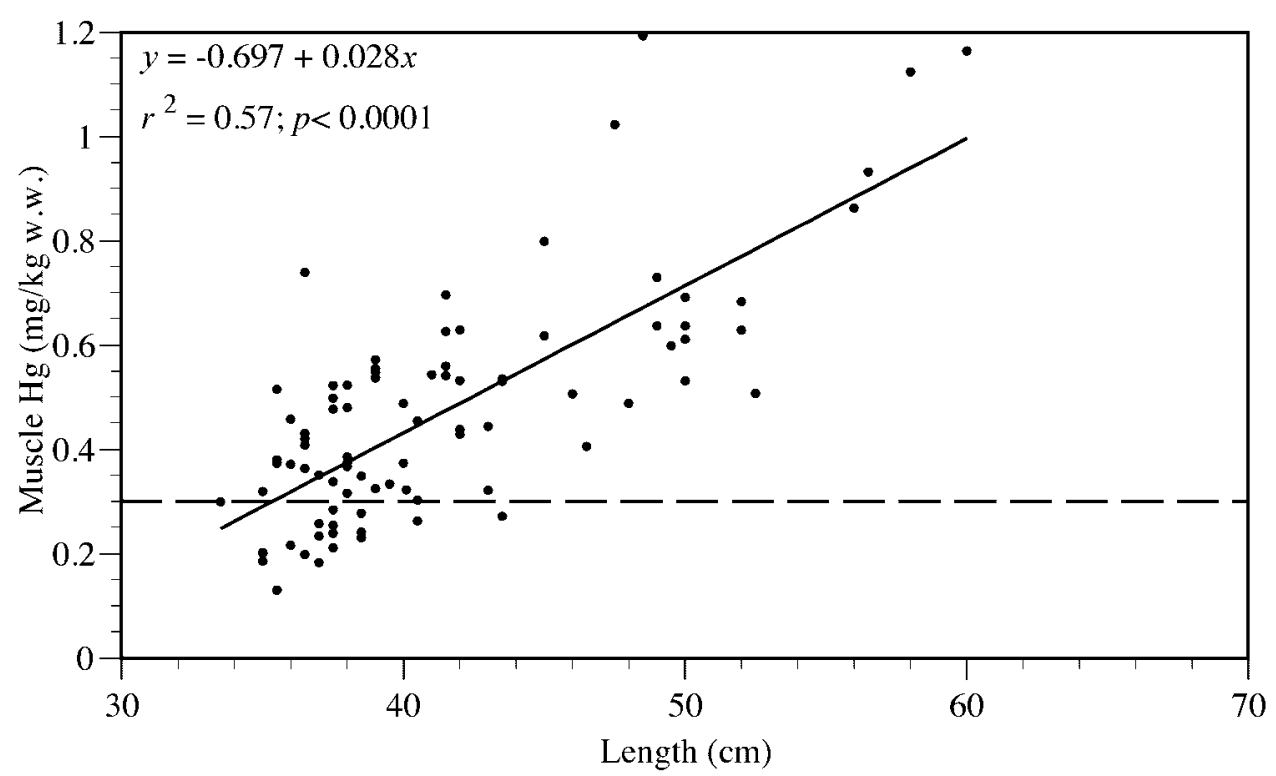

Fig. 5. Length-muscle Hg correlation for the large Micropterus salmoides, showing the regression line and equation for this collection. The dashed line represents the U.S. Environmental Protection Agency screening value $(0.300 \mathrm{mg} / \mathrm{kg})$. 
higher concentrations of $\mathrm{Hg}$ in the Rio Grande arm could be dominated by less bioavailable forms of $\mathrm{Hg}$. Thus, if environmental conditions in the Devils River arm of the reservoir are more conducive to methylation and the primary source of inorganic $\mathrm{Hg}$ inputs is more easily methylated, then it follows that $\mathrm{THg}$ and $\mathrm{MeHg}$ concentrations could be spatially decoupled between the two arms of AIR.

Amistad International Reservoir has relatively low sediment THg concentrations and should be considered unpolluted in that respect. All of the sediment samples are well below the Texas Commission on Environmental Quality's screening level of $100 \mathrm{ng} / \mathrm{g} \mathrm{THg}$. However, as the present study further demonstrates, low sediment $\mathrm{THg}$ concentrations and input do not necessarily lead to low sediment $\mathrm{MeHg}$ production and concentrations. At sites DR31 and PR74, the proportion of THg as $\mathrm{MeHg}$ exceeded 14\% during late summer, suggesting high production and bioavailability of $\mathrm{MeHg}$, yet these sites had some of the lowest $\mathrm{THg}$ concentrations sampled in the present study. It is likely that a combination of favorable environmental conditions and chemical form of inorganic $\mathrm{Hg}$ results in the elevated sediment $\mathrm{MeHg}$ concentrations.

\section{Relationship among $\mathrm{Hg}, \mathrm{MeHg}$, physiochemistry, and SRB}

In the present study, the PCA showed close alignment between the eigenvectors for porewater DOC and $\mathrm{MeHg}$, showing a correlation between the two variables (Fig. 3b). Indeed, using the site averages for sediments, there is a significant relationship between $\mathrm{MeHg}$ and porewater DOC (1/MeHg vs DOC: $\left.r^{2}=0.43, p=0.0114\right)$. The relationship between DOC and $\mathrm{Hg}$ methylation is complex, and much conflicting data can be found in the literature [1,2,4,6,42]. High levels of DOC can bind $\mathrm{Hg}$ and $\mathrm{MeHg}$ compounds, making them unavailable for either methylation or uptake [1]. Low levels of DOC can reduce the activity of microbial communities and thus have the potential to reduce methylation [1]. However, sediments often show positive correlation between $\mathrm{MeHg}$ and organic matter [1]. In the present study, the PCA indicates a weak positive correlation between sediment percent organic matter and $\mathrm{MeHg}$, but the correlation between DOC and $\mathrm{MeHg}$ was stronger (Fig. 3b). Presumably, porewater DOC is more labile than the solid-phase organic matter and more available to $\mathrm{Hg}$-methylating bacteria, thus leading to the stronger positive relationship between porewater DOC and $\mathrm{MeHg}$.

It is generally thought that the production and concentration of $\mathrm{MeHg}$ and the concentration of $\mathrm{SO}_{4}^{2-}$ are related, although the nature of the relationship depends on the $\mathrm{SO}_{4}^{2-}$ concentration range. The overall inverse relationship between $\mathrm{MeHg}$ and $\mathrm{SO}_{4}^{2-}$ concentrations in the present study (Fig. 3b) is consistent with other studies covering broad concentration ranges or studies that were conducted only at high $\mathrm{SO}_{4}^{2-}$ concentrations $[1,2]$. However, there may also be a positive relationship between $\mathrm{MeHg}$ and $\mathrm{SO}_{4}^{2-}$ when concentrations are below approximately $30 \mathrm{mg} / \mathrm{L} \mathrm{SO}_{4}^{2-}$, because $\mathrm{SRB}$ show the highest methylation potential when $\mathrm{SO}_{4}^{2-}$ concentrations are near limiting [1]. In the present study, site PR74 and sites in the Devils River arm had lower porewater $\mathrm{SO}_{4}^{2-}$ concentrations that were in the hypothesized optimum range for $\mathrm{Hg}$ methylation (1-30 mg/L) [1,3], whereas the Rio Grande arm had porewater $\mathrm{SO}_{4}^{2-}$ concentrations that ranged from 75 to $230 \mathrm{mg} / \mathrm{L}$, well above the optimum for methylation (Table 1 and the Texas Comission on Environmental Quality [16]). Thus, the results of the present study generally support the prediction that the relationship between $\mathrm{MeHg}$ and $\mathrm{SO}_{4}^{2-}$ is complex and nonlinear in nature.
Contrary to predictions, $\mathrm{MeHg}$ concentration in the sediments was not correlated with the total abundance of bacteria representing Desulfovibrionaceae or Desulfobacteriaceae, nor was sediment $\mathrm{MeHg}$ correlated with the proportion of the bacterial community composed of these groups. It is often thought that these two families are responsible for a substantial portion of $\mathrm{Hg}$ methylation [8], yet the highest bacterial numbers for both Desulfovibrionaceae and Desulfobacteriaceae were found at areas in the middle Rio Grande arm of the reservoir, where $\mathrm{MeHg}$ concentrations were relatively low. In addition, the numbers of total bacteria and numbers of SRB in sediments are not correlated with concentrations of $\mathrm{THg}, \mathrm{MeHg}, \mathrm{SO}_{4}^{2-}$, or porewater DOC in AIR as indicated by the largely orthogonal eigenvectors in the PCA (Fig. 3b). In SRB species, multiple metabolic pathways exist, the bacteria do not methylate $\mathrm{Hg}$ under all conditions $[1,8]$, and $\mathrm{Hg}$ methylation rates are often maximal at near-limiting $\mathrm{SO}_{4}^{2-}$ concentrations [1]. Thus, it is possible that conditions in the Rio Grande arm were favorable to SRB growth, allowing them to become a substantial portion of the sediment microbial community, but these conditions were not conducive to $\mathrm{Hg}$ methylation by $\mathrm{SRB}$. At concentrations $<10 \mathrm{mg} / \mathrm{L}, \mathrm{SO}_{4}^{2-}$ can become limiting to $\mathrm{SRB}$, yet, with access to organic substrates under these conditions, they have shown high methylation potentials [1]. The combination of generally low $\mathrm{SO}_{4}^{2-}$ levels and elevated levels of DOC found in the sediment pore water of the Devils River arm might have given the microbial communities near-limiting concentrations of $\mathrm{SO}_{4}^{2-}$ but ample carbon resources for metabolic activity, thus increasing $\mathrm{Hg}$ methylation rates [1,3]. This could result in higher $\mathrm{MeHg}$ concentrations, even though SRB population numbers were lower than in other parts of the reservoir. This finding supports the hypothesis that $\mathrm{Hg}$ methylation likely is not the result of the primary metabolic processes of SRB but is the result of metabolic processes that increase in importance under limiting environmental conditions [1].

In the present study, sediment $\mathrm{MeHg}$ was not related to abundances of known methylating groups. We used FISH to relate bacterial numbers to sediment $\mathrm{MeHg}$ concentrations. Although FISH is a powerful technique for quantifying specific bacterial groups and higher detection has been correlated with more active communities, total bacterial group numbers may not necessarily relate to activity, because even nutrient-starved cells are detectable if there is enough rRNA present in the cell [43]. In addition, SRB are a diverse microbial group with the ability to use a suite of alternate electron acceptors under different environmental conditions, and different species can have substantially different metabolic rates [8]. Because broad genetic probes were used, it would be possible to fail to detect discrete community shifts if the SRB responsible for the methylation of $\mathrm{Hg}$ were a small portion of the total SRB community. Thus, even substantial variation in the actively methylating SRB could have been hidden by variability in the whole SRB community. This issue is highlighted by the PCR data. Both Desulfovibrionaceae and Desulfobacteriaceae families were found throughout the reservoir using PCR and FISH. With the more specific primers, however, only sites with detections of two of the Desulfobulbus, Desulfobacter, or Desulfovibrio-Desulfomicrobium groups showed substantially elevated levels of $\mathrm{MeHg}$ in the sediment. Although the PCR method used here was not quantitative, Desulfobacter was detected at the sites with the highest $\mathrm{MeHg}$ concentrations. Whether this group or multiple groups of bacteria are the predominant methylators is unknown, but it is thought that members of the Desulfobacteriaceae (which includes 
Desulfobulbus and Desulfobacter) have a greater ability to methylate $\mathrm{Hg}$ than members of Desulfovibrionaceae [1]. Additionally, iron-reducing bacteria of the genus Geobacter can also methylate $\mathrm{Hg}$ [44]. Geobacter organisms are closely related to nonsulfate-reducing members of the $\delta$-proteobacteria (e.g., Desulfuromonas acetoxidans and Pelobacter acetylenicus), to which probe SRB-Db can hybridize [33]. In the present study, whether substantial numbers of Geobacter-type organisms were detected with this probe is unknown.

\section{Mercury bioaccumulation in largemouth bass}

In the present study, largemouth bass from the presumably less anthropogenically impacted Devils River arm [16,23] had higher levels of muscle $\mathrm{Hg}$ concentration despite the finding that these areas had lower sediment $\mathrm{THg}$ concentrations. One possible explanation is that the Devils River arm of the reservoir exhibited higher $\mathrm{Hg}$ bioavailability and transfer to the food web compared with other portions of AIR. The concentration of $\mathrm{MeHg}$ and the sediment $\mathrm{MeHg}$ :THg in the Devils River arm were consistently elevated compared with the Rio Grande arm. The elevated MeHg concentrations in the Devils River arm and $\mathrm{MeHg}: \mathrm{THg}$ above the worldwide average of approximately 1 to $1.5 \%$ for freshwater sediments suggest high $\mathrm{MeHg}$ production rates and high bioavailability to the food chain $[1,2,11,38]$. Additionally, even though AIR has $\mathrm{pH}$, alkalinity, and $\mathrm{SO}_{4}^{2-}$ in ranges that reduce the risk for elevated $\mathrm{Hg}$ in the biota $[1,4,9]$, the oligotrophic state of the reservoir likely increases the amount of $\mathrm{MeHg}$ incorporated in the biota, because oligotrophic systems can have higher than expected biota $\mathrm{Hg}$ levels $[1,4]$. Water column chlorophyll $a$ and orthophosphate-P concentrations in AIR are approximately $1.5 \mu \mathrm{g} / \mathrm{L}$ [22] and $<10 \mu \mathrm{g} / \mathrm{L}$ (A. Groeger, unpublished data), respectively. With fewer water column microorganisms to incorporate $\mathrm{MeHg}$ in oligotrophic systems, concentrations in higher trophic level biota can be elevated even when the production of $\mathrm{MeHg}$ in the sediments is the same or lower than in eutrophic systems [38].

Concentrations of $\mathrm{Hg}$ in the muscle tissue of largemouth bass are of concern under current guidelines, and they vary depending on the area of the reservoir. Larger bass have levels of muscle $\mathrm{Hg}$ that should be further investigated to assess the risk from human consumption, and this should be expanded to include the full lake and other sport fish species as well as species caught commercially in Mexico. In 2004, the U.S. EPA and U.S. Food and Drug Administration combined their recommendations into a consumption-based set of guidelines (http://www.epa.gov/waterscience/fish/advice/). These current guidelines have levels of $0.12 \mathrm{mg} / \mathrm{kg}, 0.31 \mathrm{mg} / \mathrm{kg}$, and $0.47 \mathrm{mg} /$ $\mathrm{kg}$ corresponding to a maximum of four, two, and one meal per month (http://www.epa.gov/waterscience/fishadvice/1-mealper-week.pdf). More than half of the fish in this collection exceed the $0.47 \mathrm{mg} / \mathrm{kg}$ threshold, suggesting that no more than one meal per month of largemouth bass should be consumed.

\section{CONCLUSIONS}

Understanding the spatial and temporal trends present in reservoir systems is important in determining the risks to human health. Large reservoirs can drain multiple watersheds and have highly variable biogeochemistry. Assessment of conditions at a limited number of locations in one reservoir can easily give an incomplete picture of the spatiotemporal dynamics of $\mathrm{Hg}$ pollution, and this should be taken into account in designing and prioritizing future studies and management programs. The present study shows that reservoirs in the arid West and South- west regions of the United States appear to have risk of elevated $\mathrm{Hg}$ levels in biota, even when the concentrations of inorganic $\mathrm{Hg}$ are low, they are distant from input sources, and the environmental conditions are not typically thought of as favorable to $\mathrm{MeHg}$ production and bioaccumulation.

\section{SUPPLEMENTAL DATA}

Table S1. Molecular primer and probe specifications and references (19 KB XLS).

Acknowledgement-We are indebted to R. Meyers of the Texas Parks and Wildlife Department. We thank G. Longley and the staff of the Edwards Aquifer Research and Data Center. Additionally, T. Bonner, K. Epp, A. Welsh, B. Mirza, T. Ryan, J. Strickland, and L. Fulcher were all helpful in the development and completion of this project. Sediments were collected under National Park Service Scientific Research and Collecting Permit AMIS-2007-SCI-0002. Major funding for this project was provided by the U.S. Department of Agriculture Sustainable Agricultural Water Conservation Rio Grande Program. Additional support was provided by National Science Foundation grant DGE-0742306 to W.H. Nowlin and J.C. Becker, as well as C. Nash Aquatic Studies and H.D. Schulze biology scholarships to J.C. Becker.

\section{REFERENCES}

1. Ullrich SM, Tanton TW, Abdrashitova SA. 2001. Mercury in the aquatic environment: A review of factors affecting methylation. Crit Rev Environ Sci Technol 31:241-293.

2. Benoit JM, Gilmour CC, Heyes A, Mason RP, Miller CL. 2003. Geochemical and biological controls over methylmercury production and degradation in aquatic ecosystems. In Cai Y, Braids OC, eds, Biogeochemistry of Environmentally Important Trace Elements. Symposium Series 835. American Chemical Society, Washington, DC, pp 262-297.

3. Munthe J, Bodaly RA, Branfireun BA, Driscoll CT, Gilmour CC, Harris R, Horvat M, Lucotte M, Malm O. 2007. Recovery of mercurycontaminated fisheries. Ambio 36:33-44.

4. Evers DC, Han YJ, Driscoll CT, Kamman NC, Goodale MW, Lambert KF, Holsen TM, Chen CY, Clair TA, Butler T. 2007. Biological mercury hotspots in the northeastern United States and southeastern Canada. BioScience 57:29-43.

5. Delongchamp TM, Lean DRS, Ridal JJ, Blais JM. 2009. Sediment mercury dynamics and historical trends of mercury deposition in the St. Lawrence River area of concern near Cornwall, Ontario, Canada. Sci Total Environ 407:4095-4104.

6. Belzile N, Lang CY, Chen YW, Wang M. 2008. The competitive role of organic carbon and dissolved sulfide in controlling the distribution of mercury in freshwater lake sediments. Sci Total Environ 405:226-238.

7. Batten KM, Scow KM. 2003. Sediment microbial community composition and methylmercury pollution at four mercury mineimpacted sites. Microb Ecol 46:429-441.

8. King JK, Kostka JE, Frischer ME, Saunders FM. 2000. Sulfate-reducing bacteria methylate mercury at variable rates in pure culture and in marine sediments. Appl Environ Microbiol 66:2430-2437.

9. Chen CY, Stemberger RS, Kamman NC, Mayes BM, Folt CL. 2005. Patterns of $\mathrm{Hg}$ bioaccumulation and transfer in aquatic food webs across multi-lake studies in the northeast US. Ecotoxicology 14:135-147.

10. Chumchal MM, Drenner RW, Fry B, Hambright KD, Newland LW. 2008. Habitat-specific differences in mercury concentration in a top predator from a shallow lake. Trans Am Fish Soc 137:195-208.

11. Mitchell CPJ, Branfireun BA, Kolka RK. 2008. Spatial characteristics of net methylmercury production hot spots in peatlands. Environ Sci Technol 42:1010-1016.

12. Straškraba M. 1998. Limnological differences between deep valley reservoirs and deep lakes. Int Rev Hydrobiol 83:1-12.

13. Smith A, Abuzeineh AA, Chumchal MM, Bonner TH, Nowlin WH. 2010. Mercury contamination of the fish community of a semi-arid and arid river system: spatial variation and the influence of environmental gradients. Environ Toxicol Chem 29:1762-1772.

14. Groeger AW, Kamps RH, Funk MD, Woodward D, Thompson A, Branom JR, Cave M. 2011. Mixing of the desert rivers: Limnology of the International Amistad Reservoir. Proceedings, 6th Symposium on the Natural Resources of the Chihuahuan Desert. Las Cruces, NM, USA, in press

15. U.S. Geological Survey. 1997. Water-quality trends in the Rio Grande/ Rio Bravo basin using sediment cores from reservoirs. FS-221-96. Austin, TX. 
16. Texas Comission on Environmental Quality. 2004. The effects of tributary inflow on water quality in International Amistad Reservoir (Segment 2305). AS-194. Austin, TX, USA.

17. Gray JE, Hines ME, Biester H. 2006. Mercury methylation influenced by areas of past mercury mining in the Terlingua district, Southwest Texas, USA. Appl Geochem 21:1940-1954.

18. Chumchal MM, Hambright KD. 2009. Ecological factors regulating mercury contamination of fish from Caddo Lake, Texas, USA. Environ Toxicol Chem 28:962-972.

19. Suchanek TH, Eagles-Smith CA, Slotton DG, Harner EJ, Colwell AE, Anderson NL, Mullen LH, Flanders JR, Adam DP, McElroy KJ. 2008. Spatiotemporal trends in fish mercury from a mine-dominated ecosystem: Clear Lake, California. Ecol Appl 18:A177-A195.

20. Cizdziel JV, Hinners TA, Pollard JE, Heithmar EM, Cross CL. 2002. Mercury concentrations in fish from Lake Mead, USA, related to fish size, condition, trophic level, location, and consumption risk. Arch Environ Contam Toxicol 43:309-317.

21. U.S. Environmental Protection Agency. 1997. Mercury study report to Congress. EPA-452/R-97-004. Washington DC.

22. Ground TA, Groeger AW. 1994. Chemical classification and trophic characteristics of Texas reservoirs. Lake Reservoir Manag 10:189-201.

23. U.S. Geological Survey. 2001. Water resources data Texas water year 2001. Guadalupe River basin, Nueces River basin, Rio Grande basin and Intervening Coastal basins. Water Data Report TX-01-05. Austin, TX, USA.

24. Kalff J. 2001. Limnology: Inland Water Ecosystems. Prentice-Hall, Upper Saddle River, NJ, USA

25. Zarda B, Hahn D, Chatzinotas A, Schonhuber W, Neef A, Amann RI, Zeyer J. 1997. Analysis of bacterial community structure in bulk soil by in situ hybridization. Arch Microbiol 168:185-192.

26. Sammons SM, Maceina MJ. 2005. Activity patterns of largemouth bass in a subtropical US reservoir. Fish Manag Ecol 12:331-339.

27. Morel FMM, Kraepiel AML, Amyot M. 1998. The chemical cycle and bioaccumulation of mercury. Annu Rev Ecol Syst 29:543-566.

28. Shade CW, Hudson RJM. 2005. Determination of $\mathrm{MeHg}$ in environmental sample matrices using $\mathrm{Hg}$-thiourea complex ion chromatography with on-line cold vapor generation and atomic fluorescence spectrometric detection. Environ Sci Technol 39:4974-4982.

29. U.S. Environmental Protection Agency. 1998. Method 1630: Methylmercury in water by distillation, aqueous ethylation, purge and trap, and cold vapor atomic fluorescence spectrometry. Washington, DC.

30. Welsh A, Burke DJ, Hahn D. 2007. Analysis of nitrogen-fixing members of the epsilon subclass of Proteobacteria in salt marsh sediments. Appl Environ Microbiol 73:7747-7752.
31. Amann RI, Stromley J, Devereux R, Key R, Stahl DA. 1992. Molecular and microscopic identification of sufate-reducing bacteria in multispecies biofilms. Appl Environ Microbiol 58:614-623.

32. Daly K, Sharp RJ, McCarthy AJ. 2000. Development of oligonucleotide probes and PCR primers for detecting phylogenetic subgroups of sulfatereducing bacteria. Microbiol 146:1693-1705.

33. Rabus R, Fukui M, Wilkes H, Widdel F. 1996. Degradative capacities and 16S rRNA-targeted whole-cell hybridization of sulfate-reducing bacteria in an anaerobic enrichment culture utilizing alkylbenzenes from crude oil. Appl Environ Microbiol 62:3605-3613.

34. Daims H, Bruhl A, Amann R, Schleifer KH, Wagner M. 1999. The domain-specific probe EUB338 is insufficient for the detection of all Bacteria: Development and evaluation of a more comprehensive probe set. Syst Appl Microbiol 22:434-444.

35. Taniuchi Y, Murakami A, Ohki K. 2008. Whole-cell immunocytochemical detection of nitrogenase in cyanobacteria: improved protocol for highly fluorescent cells. Aquat Microb Ecol 51:237-247.

36. McCune B, Grace JB. 2002. Analysis of ecological communities. MjM Software Design, Gleneden Beach, OR, USA.

37. Tremblay G, Legendre P, Doyon JF, Verdon R, Schetagne R. 1998. The use of polynomial regression analysis with indicator variables for interpretation of mercury in fish data. Biogeochemistry 40:189-201.

38. Suchanek TH, Eagles-Smith CA, Harner EJ. 2008. Is Clear Lake methylmercury distribution decoupled from bulk mercury loading? Ecol Appl 18:A107-A127.

39. Foody GM, Ghoneim EM, Arnell NW. 2004. Predicting locations sensitive to flash flooding in an arid environment. J Hydrol 292:48-58.

40. U.S. Geological Survey. 1997. Trace elements and organic compounds associated with with riverbed sediments in the Rio Grande/Rio Bravo basin, Mexico and Texas. FS-098-97. Washington, DC.

41. Barnes VE. 1992. Geologic Map of Texas. SM0003. Bureau of Economic Geology, University of Texas at Austin, Austin, TX, USA.

42. Kamman NC, Lorey PM, Driscoll CT, Estabrook R, Major A, Pientka B, Glassford E. 2004. Assessment of mercury in waters, sediments, and biota of New Hampshire and Vermont lakes, USA, sampled using a geographically randomized design. Environ Toxicol Chem 23:11721186.

43. Bouvier T, del Giorgio PA. 2003. Factors influencing the detection of bacterial cells using fluorescence in situ hybridization (FISH): A quantitative review of published reports. FEMS Microbiol Ecol 44:3-15.

44. Fleming EJ, Mack EE, Green PG, Nelson DC. 2006. Mercury methylation from unexpected sources: Molybdate-inhibited freshwater sediments and an iron-reducing bacterium. Appl Environ Microbiol 72:457-464. 